Article

\title{
An Improved Heating System with Waste Pressure Utilization in a Combined Heat and Power Unit
}

\author{
Heng Chen ${ }^{\mathbb{D}}$, Jidong $\mathrm{Xu}$, Yao Xiao, Zhen Qi, Gang $\mathrm{Xu}$ * and Yongping Yang \\ National Thermal Power Engineering and Technology Research Center, North China Electric Power University, \\ Beijing 102206, China; heng@ncepu.edu.cn (H.C.); 18810788663@163.com (J.X.); Xyaoncepu@163.com (Y.X.); \\ qizhenhdnd@163.com (Z.Q.); yyp@ncepu.edu.cn (Y.Y.) \\ * Correspondence: xgncepu@163.com; Tel.: +86-(10)-6177-2472
}

Received: 6 May 2018; Accepted: 4 June 2018; Published: 11 June 2018

check for updates

\begin{abstract}
An improved heating system integrated with waste pressure utilization (WPU) for combined heat and power (CHP) cogeneration was proposed. The new heating system efficiently utilized the excess pressure of the extraction heating steam to drive the WPU turbine and generator for producing electricity, achieving higher energy efficiency and lower fuel consumption of the $\mathrm{CHP}$ unit. The results of the detailed thermodynamic analysis showed that applying the proposed concept in a typical $300 \mathrm{MW}$ coal-fired CHP unit could reduce the standard coal consumption rate by $9.84 \mathrm{~g} /(\mathrm{kW} \cdot \mathrm{h})$, with a thermal efficiency improvement of $1.97 \%$ (absolute value). Compared to that of the original heating process, the energy efficiency of the proposed process decreased by $0.55 \%$ (absolute value), but its exergy efficiency increased dramatically by $17.97 \%$ (absolute value), which meant that the proposed configuration could make better use of the steam energy and contribute to the better performance of the CHP unit. As the unit generation load and supply and return-water temperatures declined and the unit heating load rose, the WPU system would generate more electricity and its energy-saving benefit would be enhanced. This work provides a promising approach to further advance the CHP technology and district heating systems.
\end{abstract}

Keywords: combine heat and power; heating system; waste pressure utilization; thermodynamic analysis; energy-saving

\section{Introduction}

Combined heat and power (CHP) as a cogeneration system can produce power and heat at the same time, which has the advantages of energy cascade utilization, significant flexibility, and high efficiency [1-4]. CHP is an important approach to reduce the primary energy demand from fossil fuels and cut down $\mathrm{CO}_{2}$ emissions [5-8]. Thus, the $\mathrm{CHP}$ technology has been widely used all around the world [9-11]. In China, the capacity of installed CHP units has reached 300 million kilowatt since 2016, accounting for about $30 \%$ of the total thermal power capacity [12]. The overall efficiency of CHP is from $60 \%$ to $80 \%$, which is much higher than the $40 \%$ average efficiency of typical coal-burning power plants $[13,14]$. However, there is still huge energy-saving potential in CHP units, such as the waste, heat, and pressure of the heating systems, which can possibly be utilized by process optimization. It is essential to recover the waste energy of CHP and promote its energy efficiency.

In a regular CHP unit, the steam is extracted from the communication pipe between the intermediate-pressure cylinder and low-pressure cylinder of the steam turbine, heating the supply-water of the first-class thermal network. Generally, the pressure of the extraction steam is $0.3-0.5 \mathrm{MPa}$ (the corresponding saturation temperature is $133.53-151.84{ }^{\circ} \mathrm{C}$ ), and the designed supply-water temperature is $120-130{ }^{\circ} \mathrm{C}$ [15]. But because of climate change and energy-efficient building technologies, the actual supply-water temperature has decreased to approximately 
90-100 ${ }^{\circ} \mathrm{C}[16]$, and the needed steam pressure (the saturation pressure in the supply-water heater) for heating is only about $0.10-0.14 \mathrm{MPa}$ (the terminal temperature difference of the supply-water heater should be kept larger than $10^{\circ} \mathrm{C}$ to guarantee its high heat exchange efficiency [17]). Therefore, the exergy loss caused by superfluous steam pressure is enormous in the practical heating process, based on the second law of thermodynamics, which is necessary to be reduced for conserving energy and increasing the useful energy output of the CHP unit.

A number of studies have been done regarding the waste energy recovery of CHP [18]. Some scholars have explored the application of absorption heat pumps (AHPs) to recover the waste heat of steam turbines. Li [19], Sun [20], and Kang [21] have proposed several CHP systems with AHP for district heating and have analyzed their energy-saving effects. Soltani [22] and Shukla [23] did the thermodynamic and parametric investigation of the AHP cycles for CHP. A volume of work has been devoted to increasing the back pressure of the steam turbine and directly heating the supply-water of the thermal network with the exhaust steam. Feng [24] and Wang [25] have discussed the system optimization and operation modification of CHP units with high back-pressure heating technology. Li $[26,27]$ and Sun $[28,29]$ set up absorption heat exchange (AHE) units at the thermal substations to decrease the return-water temperature of the thermal network, and evaluated the performances of the new designs. The AHE units with high-temperature supply-water of the primary thermal network can bring the return-water temperature down to $20^{\circ} \mathrm{C}$ or less, which helps to recover more low-temperature waste heat. Above all, most of the literature focuses on the waste heat of steam turbines. However, the waste pressure of the heating system has seldom been discussed in recent years, and little information has been published concerning the waste pressure utilization (WPU) during the heating process of CHP.

In the present paper, an improved heating system with WPU for CHP is proposed. The thermodynamic and economic characteristics of the new heating configuration were theoretically analyzed. The effects of the unit generation load, the unit heating load, and the supply and return-water temperatures of the thermal network on the thermal performance of the proposed system were also synthetically investigated. Our objective was to clarify the energy-saving mechanism of WPU in the heating system of CHP, which would be beneficial to enhancing the overall efficiency of CHP and lowering its fuel consumption.

\section{Concept Proposal}

In order to take advantage of the waste energy of the extracted heating steam from the intermediate-pressure cylinder, a new heating concept with a WPU system was put forward, as depicted in Figure 1. First, the extraction steam (0.3-0.5 MPa) expands to do work in the WPU turbine and its pressure will decline to about $0.1 \mathrm{MPa}$ or less. Then, the WPU turbine drives the WPU generator and the extra pressure of the extraction steam will be converted into electricity. The generated electricity of the WPU system can be used by the pumps, fans, and so on in the CHP unit as auxiliary power, or it can be delivered to the power consumers by the power grids connected with the CHP unit. The waste pressure of the extraction steam can be effectively employed in the proposed system with energy cascade utilization, enhancing the overall performance of the CHP unit and resulting in a lot of economic benefits. As the minimum heating steam pressure that is needed by the supply-water heater changes with the supply-water temperature, the exhaust pressure of the WPU turbine can adjust to the requested steam pressure for heating, keeping the heating system running efficiently. 


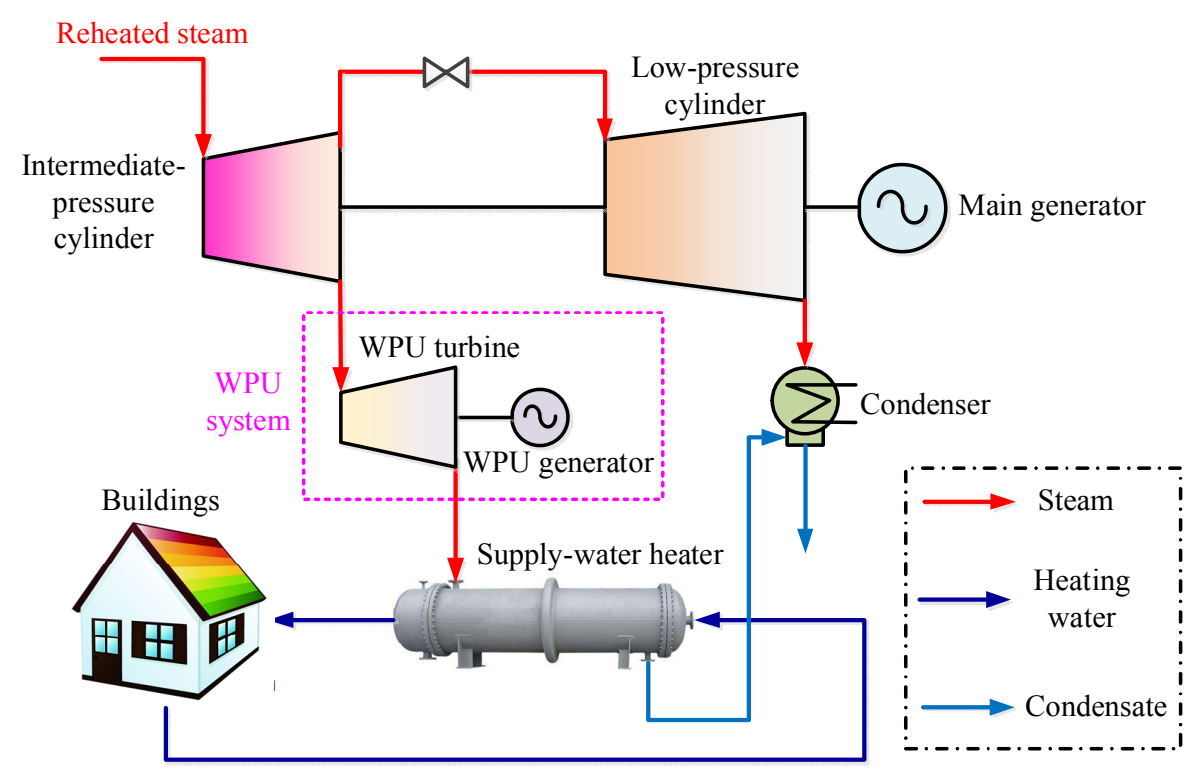

Figure 1. Diagram of the proposed heating system with waste pressure utilization (WPU).

\section{Reference CHP Unit}

A 300 MW coal-burning CHP unit in the northwest of China was selected as a reference case in this study. The heating season of this CHP unit is from October to April of the next year. As shown in Figure 2, the steam turbine is a single-reheating, double-exhausting, and direct air-cooling condensing turbine, which is associated with a subcritical circulating fluidized bed boiler. The regenerative system is constructed of three high-pressure heaters, three low-pressure heaters, and one deaerator. The steam is extracted from the intermediate-pressure cylinder to heat the supply-water in the supply-water heater. The pressure of the exhaust steam from the intermediate-pressure cylinder is maintained above $0.4 \mathrm{MPa}$ by the throttling valve, to ensure the safety of the last stage blades of the intermediate-pressure cylinder.

The main parameters of the case CHP unit are presented in Table 1. The designed supply and return-water temperatures were $130^{\circ} \mathrm{C}$ and $70{ }^{\circ} \mathrm{C}$, respectively. However, with the climate warming and the application of building energy-saving technologies, the supply and return-water temperatures have fallen in recent years. According to the operation data of the CHP unit during the heating season from October 2016 to April 2017, the average supply and return-water temperatures and the unit heating load in different months are summarized in Figure 3. These data suggest that the supply-water temperature is positively correlated to the return-water temperature and that they change with the season synchronously. The difference between the supply and return-water temperatures rises when the supply-water temperature increases. The supply and return-water temperatures also have a positive relationship with the heating load of the CHP unit. When the weather gets cold, the unit heating load is high, and the peak mean supply and return-water temperatures are $95^{\circ} \mathrm{C}$ and $50^{\circ} \mathrm{C}$. However during the warm months, the unit heating load becomes relatively low and the minimum average supply and return-water temperatures are only $65^{\circ} \mathrm{C}$ and $40{ }^{\circ} \mathrm{C}$, respectively. 


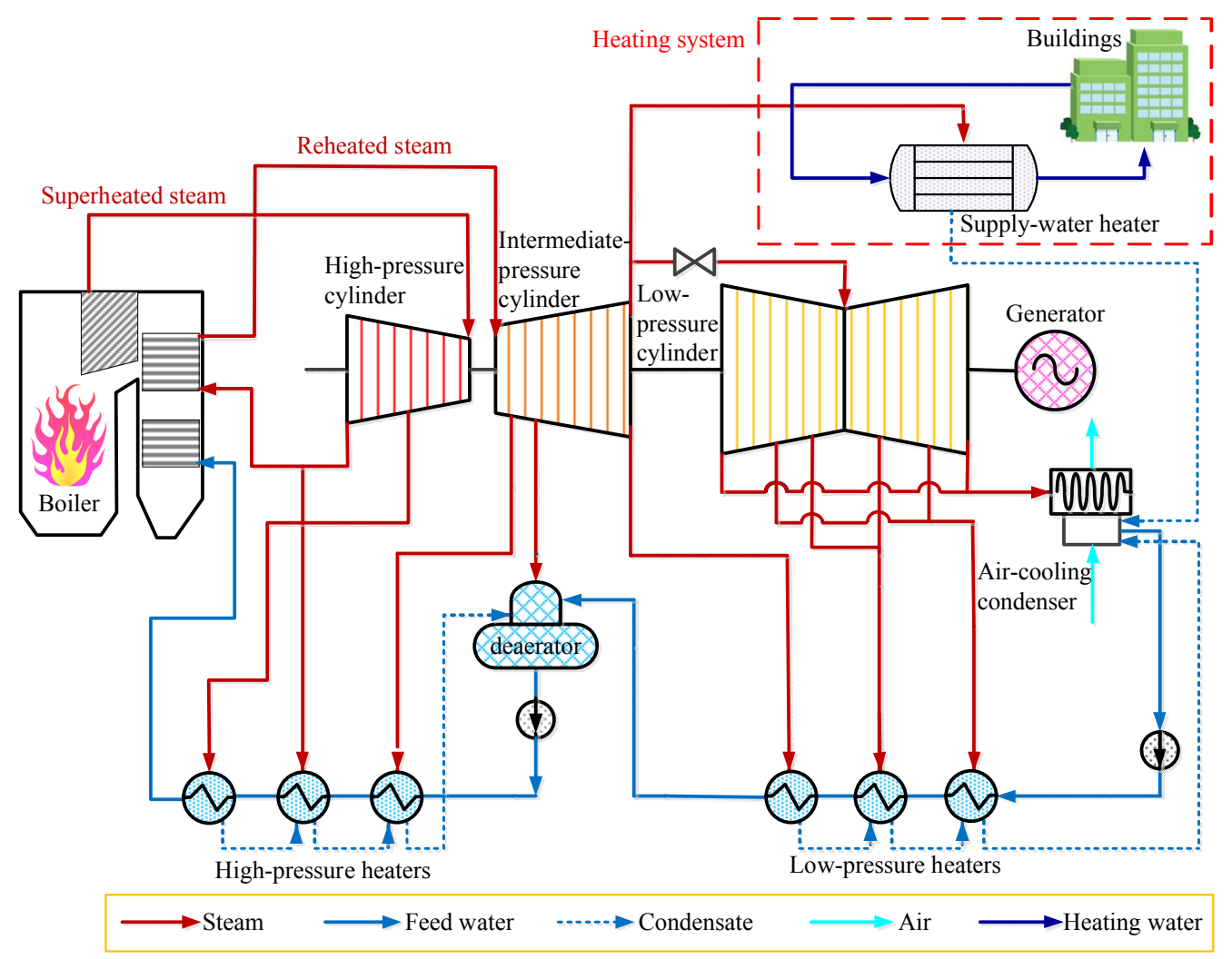

Figure 2. Diagram of the reference combined heat and power (CHP) unit with a regular heating system.

Table 1. Main parameters of the reference combined heat and power (CHP) unit under the rated condition in the heating season.

\begin{tabular}{lcc}
\hline \multicolumn{1}{c}{ Parameter } & Unit & Value \\
\hline Flow rate of the main steam & $\mathrm{t} / \mathrm{h}$ & 906.42 \\
Pressure of the main steam & $\mathrm{MPa}$ & 16.67 \\
Temperature of the main steam & 538 \\
Flow rate of the reheated steam & $\mathrm{C} / \mathrm{h}$ & 755.98 \\
Pressure of the reheated steam & $\mathrm{MPa}$ & 3.16 \\
Temperature of the reheated steam & ${ }^{\circ} \mathrm{C}$ & 538 \\
Exhaust steam flow rate of the low-pressure cylinder & $\mathrm{t} / \mathrm{h}$ & 346.30 \\
Exhaust steam pressure of the low-pressure cylinder & $\mathrm{kPa}$ & 14 \\
Pressure of the extracted heating steam from the intermediate-pressure cylinder & $\mathrm{MPa}$ & 0.40 \\
Flow rate of the extracted heating from the intermediate-pressure cylinder & $\mathrm{t} / \mathrm{h}$ & 261.66 \\
Designed temperature of the condensate from the heating steam & ${ }^{\circ} \mathrm{C}$ & 104 \\
Actual temperature of the condensate from the heating steam & ${ }^{\circ} \mathrm{C}$ & 55 \\
Heating load of the CHP unit & $\mathrm{MW}$ & 200 \\
Generation load of the CHP unit & $\mathrm{MW}$ & 250 \\
Designed supply-water temperature of the thermal network & ${ }^{\circ} \mathrm{C}$ & 130 \\
Actual supply-water temperature of the thermal network & ${ }^{\circ} \mathrm{C}$ & 95 \\
Designed return-water temperature of the thermal network & ${ }^{\circ} \mathrm{C}$ & 70 \\
Actual return-water temperature of the thermal network & ${ }^{\circ} \mathrm{C}$ & 50 \\
Power generation thermal efficiency of the CHP unit & ${ }^{\circ}$ & 48.62 \\
Power generation standard coal consumption rate of the CHP unit & $\mathrm{g} /(\mathrm{kW} \cdot \mathrm{h})$ & 252.96 \\
\hline
\end{tabular}




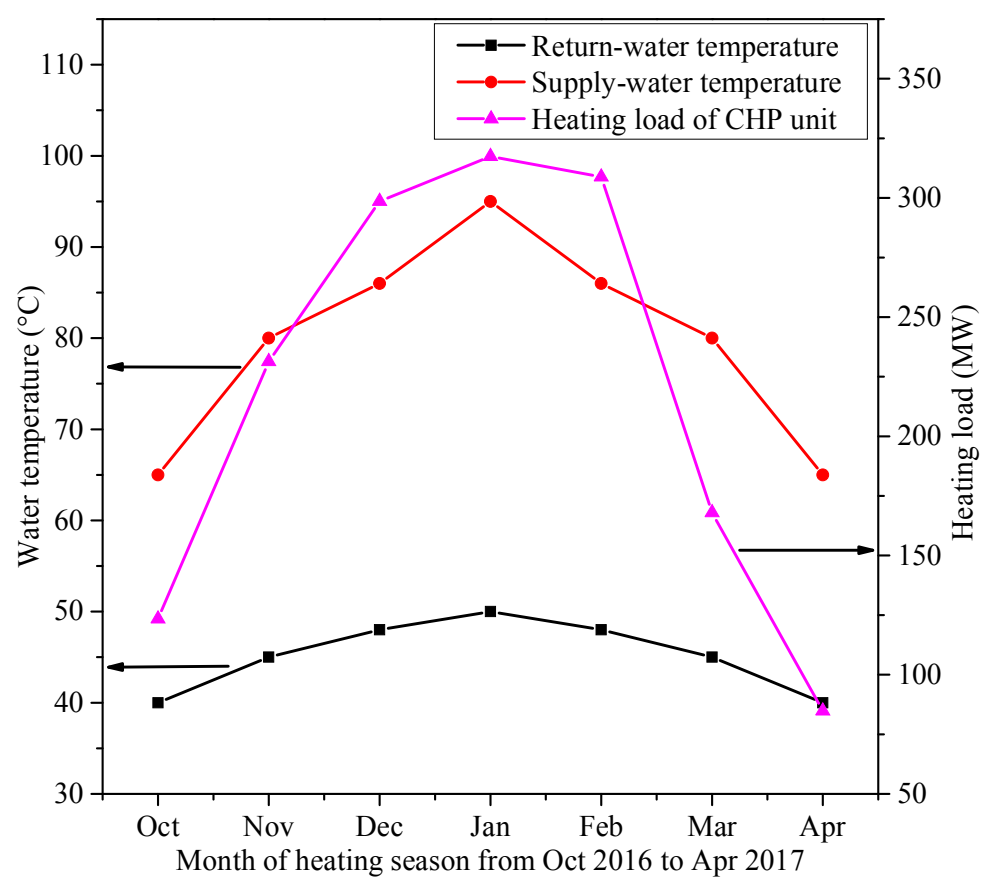

Figure 3. Average supply and return-water temperatures of the thermal network and heating load of the CHP unit in different months during the heating season from October 2016 to April 2017.

According to engineering experience, the terminal temperature difference of the supply-water heater (the terminal temperature difference is equal to the saturation temperature minus the supply-water temperature) is usually about $10^{\circ} \mathrm{C}$ or higher, which can ensure the economic operation of the heater [30]. As the supply-water temperature declines, the required heating steam pressure (saturation pressure) becomes smaller, and the theoretical lowest steam pressures that were needed by the heater corresponding to different supply-water temperatures were calculated, as displayed in Table 2. The pressure loss in the practical heating process was more than $0.28 \mathrm{MPa}$, which is a great waste of energy. Based on the second law of thermodynamics, there is also a lot of exergy loss owing to the distinct steam pressure decay, leading to low energy utilization efficiency. The proposed design with WPU can be applied in this CHP unit to recover the waste energy and to promote the thermal performance of the unit. The thermodynamic characteristic of the improved CHP unit was analyzed in this paper, and was compared with the original unit.

Table 2. Theoretical pressure loss during the actual heating process under different supply and return-water temperatures.

\begin{tabular}{lccccc}
\multicolumn{1}{c}{ Item } & Unit & \multicolumn{3}{c}{ Value } \\
\hline Supply-water temperature & ${ }^{\circ} \mathrm{C}$ & 95 & 86 & 80 & 65 \\
\hline Return-water temperature & ${ }^{\circ} \mathrm{C}$ & 50 & 48 & 45 & 40 \\
\hline $\begin{array}{l}\text { Pressure of the extraction steam from the } \\
\text { intermediate-pressure cylinder }\end{array}$ & $\mathrm{MPa}$ & $\geq 0.40$ & $\geq 0.40$ & $\geq 0.40$ & $\geq 0.40$ \\
$\begin{array}{l}\text { Theoretical lowest heating steam pressure } \\
\text { needed by the supply-water heater }{ }^{1}\end{array}$ & $\mathrm{MPa}$ & 0.12 & 0.09 & 0.07 & 0.04 \\
\hline $\begin{array}{l}\text { Theoretical pressure loss } \\
1\end{array}$ & $\mathrm{MPa}$ & $\geq 0.28$ & $\geq 0.31$ & $\geq 0.33$ & $\geq 0.36$ \\
\hline
\end{tabular}




\section{Thermodynamic Analysis}

\subsection{Energy Evaluation Method}

The thermal performance of the CHP unit without or with the proposed concept were analyzed by the heat distribution method [31], as follows.

The total heat consumption of the CHP unit is $Q_{\mathrm{tp}}^{\prime}(\mathrm{MW})$.

$$
Q_{\mathrm{tp}}^{\prime}=\frac{m_{0}^{\prime}\left(h_{0}-h_{\mathrm{fw}}\right)+m_{\mathrm{rh}}^{\prime}\left(h_{\mathrm{rh}, 0}-h_{\mathrm{rh}, \mathrm{c}}\right)}{3600 \eta_{\mathrm{b}} \eta_{\mathrm{p}}}
$$

where $m_{0}^{\prime}$ is the flow rate of the main steam, $\mathrm{t} / \mathrm{h} m_{\mathrm{rh}}^{\prime}$ is the flow rate of the reheated steam, $\mathrm{t} / \mathrm{h} ; h_{0}$ is the enthalpy of the main steam, $\mathrm{kJ} / \mathrm{kg}$; $h_{\mathrm{fw}}$ is the enthalpy of the feed-water; $\mathrm{kJ} / \mathrm{kg} ; h_{\mathrm{rh}, 0}$ is the enthalpy of the reheated steam, $\mathrm{kJ} / \mathrm{kg} ; h_{\mathrm{rh}, \mathrm{c}}$ is the enthalpy of the reheated steam in the cold section, $\mathrm{kJ} / \mathrm{kg} ; \eta_{\mathrm{b}}$ is the boiler efficiency, which was chosen to be 0.91 ; and $\eta_{\mathrm{p}}$ is the pipe thermal efficiency, which was chosen to be 0.99 .

The heat consumption for the heating of the CHP unit is $Q_{\mathrm{tp}(\mathrm{h})}^{\prime}(\mathrm{MW})$.

$$
Q_{\mathrm{tp}(\mathrm{h})}^{\prime}=\frac{m_{\mathrm{h}}^{\prime}\left(h_{\mathrm{h}}-h_{\mathrm{h}}^{\prime}\right)}{3600 \eta_{\mathrm{b}} \eta_{\mathrm{p}}}
$$

where $m_{\mathrm{h}}^{\prime}$ is the flow rate of the extraction steam for heating from the intermediate-pressure cylinder, $\mathrm{t} / \mathrm{h} ; h_{\mathrm{h}}$ is the enthalpy of the extraction steam for heating, $\mathrm{kJ} / \mathrm{kg}$; and $h_{\mathrm{h}}^{\prime}$ is the enthalpy of the condensate of the extraction steam after heating, $\mathrm{kJ} / \mathrm{kg}$.

The heat consumption for the power generation of the CHP unit is $Q_{\mathrm{tp}(\mathrm{e})}^{\prime}(\mathrm{MW})$.

$$
Q_{\mathrm{tp}(\mathrm{e})}^{\prime}=Q_{\mathrm{tp}}^{\prime}-Q_{\mathrm{tp}(\mathrm{h})}^{\prime}
$$

The power generation thermal efficiency of the CHP unit is $\eta_{\mathrm{tp}(\mathrm{e})}$.

$$
\eta_{\mathrm{tp}(\mathrm{e})}=\frac{P_{\mathrm{e}}}{Q_{\mathrm{tp}(\mathrm{e})}^{\prime}}
$$

where $P_{\mathrm{e}}$ is the generation power of the unit, MW.

The power generation thermal efficiency improvement (absolute value) that is caused by the proposed concept is $\Delta \eta_{\mathrm{tp}(\mathrm{e})}$.

$$
\Delta \eta_{\mathrm{tp}(\mathrm{e})}=\eta_{\mathrm{tp}(\mathrm{e})-\text { new }}-\eta_{\mathrm{tp}(\mathrm{e})-\mathrm{old}}
$$

where $\eta_{\mathrm{tp}(\mathrm{e})-\text { new }}$ is the power generation thermal efficiency of the new unit with the proposed design; $\eta_{\mathrm{tp}(\mathrm{e}) \text {-old }}$ is the power generation thermal efficiency of the original unit without the proposed design.

The power generation standard coal consumption rate of the CHP unit is $b_{\mathrm{tp}(\mathrm{e})}^{\mathrm{s}}(\mathrm{g} /(\mathrm{kW} \cdot \mathrm{h}))$.

$$
b_{\mathrm{tp}(\mathrm{e})}^{\mathrm{s}}=\frac{123}{\eta_{\mathrm{tp}(\mathrm{e})}}
$$

The power generation standard coal consumption rate reduction (absolute value) because of the proposed concept is $\Delta b_{\mathrm{tp}(\mathrm{e})}^{\mathrm{s}}(\mathrm{g} /(\mathrm{kW} \cdot \mathrm{h}))$.

$$
\Delta b_{\mathrm{tp}(\mathrm{e})}^{\mathrm{s}}=b_{\mathrm{tp}(\mathrm{e})-\mathrm{old}}^{\mathrm{s}}-b_{\mathrm{tp}(\mathrm{e})-\text { new }}^{\mathrm{s}}
$$

where $b_{\mathrm{tp}(\mathrm{e})-\text { new }}^{\mathrm{s}}$ is the power generation thermal efficiency of the new unit with the proposed configuration, $\mathrm{g} /(\mathrm{kW} \cdot \mathrm{h}) ; b_{\mathrm{tp}(\mathrm{e}) \text {-old }}^{\mathrm{s}}$ is the power generation thermal efficiency of the original unit without the proposed configuration, $\mathrm{g} /(\mathrm{kW} \cdot \mathrm{h})$. 
The energy efficiency of the heating process is $\eta_{\mathrm{en}}$, which is defined as the ratio of the effectively used energy to the total energy that has been consumed by the heating system.

$$
\eta_{\mathrm{en}}=1-\frac{\Delta Q^{\prime}}{Q_{\text {in }}^{\prime}-Q_{\text {out }}^{\prime}}
$$

where $\Delta Q^{\prime}$ is the energy loss of the heating is process, $M W ; Q_{\text {in }}^{\prime}$ is the inlet energy of the heating process, MW; and $Q_{\text {out }}^{\prime}$ is the outlet energy of the heating process, MW.

The exergy efficiency of the heating process is $\eta_{\mathrm{ex}}$, which considers the different grades of energy flows based on the second law of thermodynamics, was also adopted here to assess the performance of the heating system.

$$
\eta_{\mathrm{ex}}=1-\frac{\Delta E^{\prime}}{E_{\text {in }}^{\prime}-E_{\text {out }}^{\prime}}
$$

where $\Delta E^{\prime}$ the exergy loss of the heating is process MW; $E_{\mathrm{in}}^{\prime}$ is the inlet exergy of the heating process, $\mathrm{MW}$; and $E_{\text {out }}^{\prime}$ is the outlet exergy of the heating process, MW.

\subsection{Simulation Model}

The off-design operation parameters of the original and improved CHP units were calculated on the software EBSILON (STEAG Energy Services, Essen, Germany), which employs a matrix solution method, requiring the linearization of all dependencies. To consider the influences resulting from non-linearities, a Newton iteration was performed afterwards. If the deviation from the previous iteration step was smaller than the specified precision value (usually chosen as $10^{-7}$ ) for all of the matrix cells, the iteration would stop. Figure 4 shows the simulation model of the unit without or with the WPU design, which was built on the basis of mass balance and energy balance. The two units were simulated under different conditions and the corresponding thermal performances were evaluated.

To verify the availability and accuracy of the EBSILON simulation model, the total generation power of the original CHP unit was calculated under the operating conditions of turbine heat acceptance (THA), as well as 75\% THA, 50\% THA, 40\% THA, and 30\% THA.

The relative error of the calculated unit generation power is defined as follows:

$$
\delta_{\mathrm{e}}=\frac{P_{\mathrm{e}-\mathrm{c}}-P_{\mathrm{e}-\mathrm{p}}}{P_{\mathrm{e}-\mathrm{p}}} \times 100 \%
$$

where $\delta_{\mathrm{e}}$ is the relative error of the calculated unit generation is power, $\% ; P_{\mathrm{e}-\mathrm{p}}$ is the practical generation power of the original unit, $\mathrm{MW}$; and $P_{\mathrm{e}-\mathrm{c}}$ is the calculated generation power of the original unit, MW.

The calculation results were compared with the actual running data of this unit that were obtained from its formal performance test in 2015, which was taken by a professional institute, based on related testing standards of thermal power plants. The practical generation powers of different conditions in Table 3 are the average measured values during the performance test. Table 3 shows that the maximum relative error of the calculated results is merely $0.77 \%$, which indicates that the simulation model is reliable and precise. 


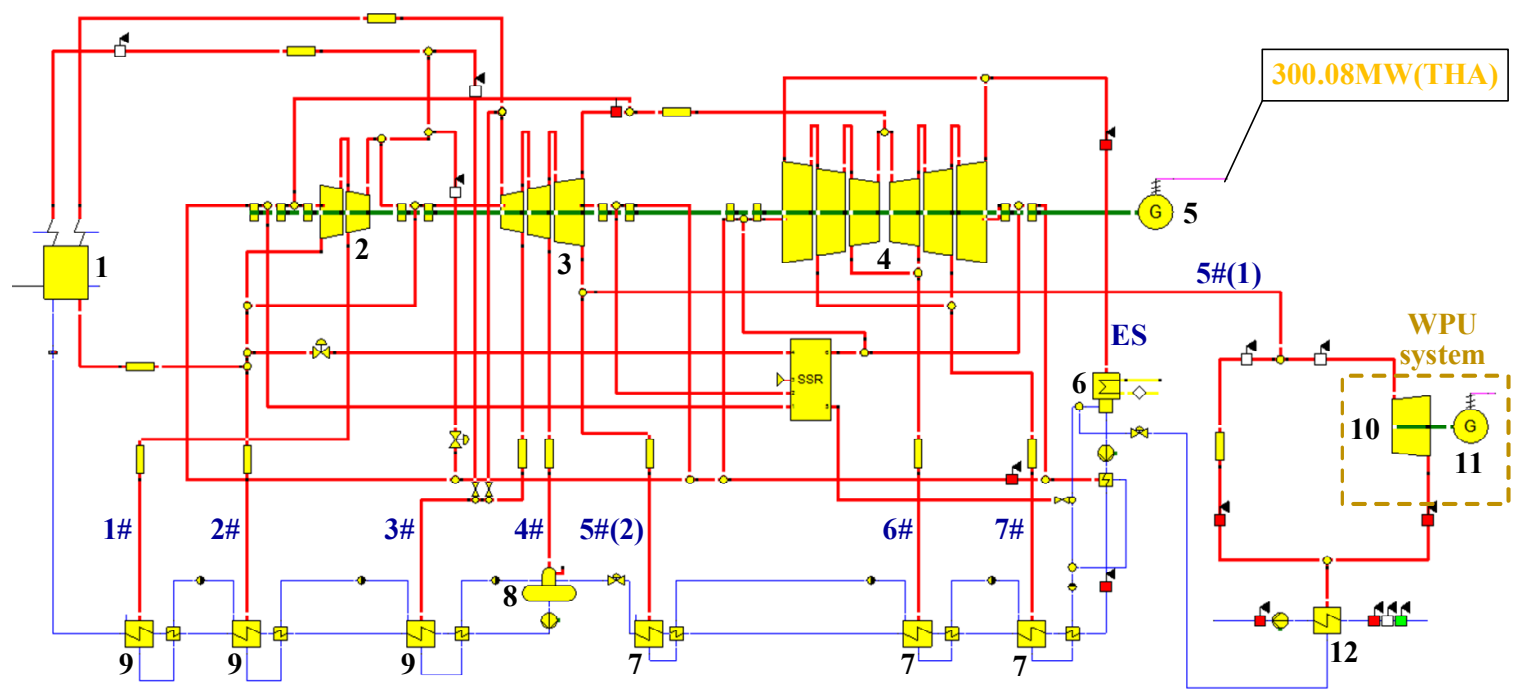

Figure 4. Simulation model of the CHP unit without or with the proposed concept. 1-Boiler; 2-high-pressure cylinder; 3-intermediate-pressure cylinder; 4-low-pressure cylinder; 5-main generator; 6-condenser; 7-low-pressure heater; 8-deaerator; 9-high-pressure heater; 10-WPU turbine; 11-WPU generator; 12 - supply-water heater.

Table 3. Relative error of the calculated unit generation power by the simulation model under different operation conditions. THA — turbine heat acceptance; MW-heat.

\begin{tabular}{cccc}
\hline Operation Condition & $\begin{array}{c}\text { Practical Value } \\
\text { (MW) }\end{array}$ & $\begin{array}{c}\text { Calculated Value } \\
\text { (MW) }\end{array}$ & $\begin{array}{c}\text { Relative Error } \\
\text { (\%) }\end{array}$ \\
\hline THA & 300.23 & 300.08 & -0.05 \\
$75 \%$ THA & 225.10 & 225.72 & +0.27 \\
$50 \%$ THA & 150.06 & 150.40 & +0.23 \\
$40 \%$ THA & 120.07 & 120.71 & +0.54 \\
$30 \%$ THA & 90.06 & 90.75 & +0.77 \\
\hline
\end{tabular}

\section{Results and Discussion}

\subsection{Basic Analysis}

Based on the simulation results that were achieved by software EBSILON under the rated heating condition, the thermal performances of the regular and proposed units were assessed and are summarized in Table 4. The supply and return-water temperatures were set as $95{ }^{\circ} \mathrm{C}$ and $50{ }^{\circ} \mathrm{C}$ under the nominal condition. The isentropic efficiency of the WPU turbine and the power generation efficiency of the WPU generator were chosen as 0.75 and 0.92 , respectively. The main steam flow rate remained constant for the original and improved units. The results implied that the power generation thermal efficiency of the unit had risen from $48.62 \%$ to $50.59 \%$, because of the WPU design, which caused that the power generation standard coal consumption rate to decline by $9.84 \mathrm{~g} /(\mathrm{kW} \cdot \mathrm{h})$. Figure 5 suggests that the $5 \#$ stage extraction steam for the heating increased by $19.37 \mathrm{t} / \mathrm{h}$, which resulted less steam doing work in the low-pressure cylinder, and the power output of the main generator dropped by 3.51 MW. However, the WPU system generated 13.64 MW electricity and the exhaust steam of the low-pressure cylinder fell by $19.10 \mathrm{t} / \mathrm{h}$, which cut down the energy loss to the ambient in the condenser. Therefore, the total generation of power of the CHP unit was improved by $10.13 \mathrm{MW}$, which was owing to the proposed concept. If the improved unit operated under the rated condition all through the day, 59.04 tons of standard coal were saved and the corresponding economic benefit may have reached 519,600 Chinese Yuan (the price of standard coal was set as 880 Chinese Yuan per ton [32]). 
To sum up, it was evident that the proposed WPU system could remarkably recover the waste energy of the extracted heating steam for and promote the overall efficiency of the CHP unit.

Table 4. Overall performances of the original and improved CHP units.

\begin{tabular}{lccc}
\hline \multicolumn{1}{c}{ Item } & Original Unit & Improved Unit & $\begin{array}{c}\text { Difference } \\
\text { (Absolute Value) }\end{array}$ \\
\hline Main steam flow rate $(\mathrm{t} / \mathrm{h})$ & 906.42 & 906.42 & 0 \\
\hline $\begin{array}{l}\text { Flow rate of the extracted heating steam from the } \\
\text { intermediate-pressure cylinder of the main turbine }(\mathrm{t} / \mathrm{h})\end{array}$ & 261.66 & 281.03 & +19.37 \\
\hline Heating load of the unit (MW) & 200 & 200 & 0 \\
\hline Generation power of the main generator (MW) & 250 & 246.49 & -3.51 \\
\hline Generation power of the WPU generator (MW) & 0 & 13.64 & +13.64 \\
\hline Total generation load of the unit (MW) & 250 & 260.13 & +10.13 \\
\hline Power generation thermal efficiency of the unit $(\%)$ & 48.62 & 50.59 & +1.97 \\
\hline $\begin{array}{l}\text { Power generation standard coal consumption rate of the } \\
\text { unit }(\mathrm{g} /(\mathrm{kW} \cdot \mathrm{h}) \text { ) }\end{array}$ & 252.96 & 243.12 & -9.84 \\
\hline
\end{tabular}

${ }^{1}$ The value difference (absolute value) is equal to the value of the improved unit minus that of the original unit.

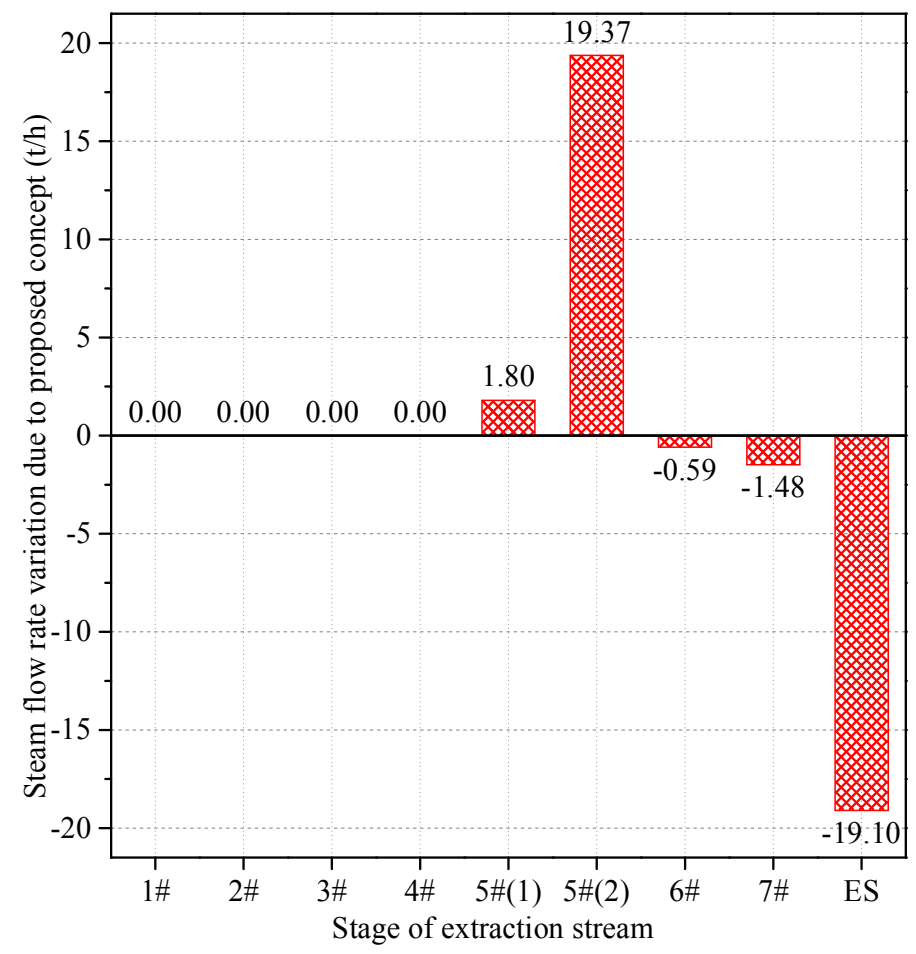

Figure 5. Flow rate variation of the extraction steam for each stage in the proposed unit compared with the original unit (5\#(1) represents the $5 \#$ stage extraction steam into the supply-water heater; $5 \#(2)$ represents the 5\# stage extraction steam into the low-pressure heater; ES represents the exhaust steam from the low-pressure cylinder).

To further reveal the energy recovery mechanism of the WPU concept, the energy flow and exergy flow diagrams of the heating processes were drawn, as illustrated in Figures 6 and 7. Only the energy and exergy flows that occurred in the heating process that were associated with the supply-water heater were considered, focusing on the heat exchange between the extracted heating steam and the supply-water, and the heat loss as a result of radiation was neglected in the heating process. In addition, the energy and exergy efficiencies of the original and improved heating processes were calculated 
using Equations (8) and (9), based on the energy and exergy flows in Figures 6 and 7, as presented in Figure 8 . These data show that more energy entered into the WPU heating system and that most of the additional inlet energy was transformed into electricity. The energy efficiency of the new process was $0.55 \%$ (absolute value) lower than that of the original one, which was mainly caused by the losses of the WPU turbine and generator. However, the exergy efficiency of the heating process was promoted by $17.97 \%$ (absolute value), owing to the WPU design, primarily because the exergy loss of the heating process fell from $45.84 \%$ to $20.71 \%$. It appeared that the energy utilization of the proposed heating process was much more reasonable and sufficient, based on the second law of thermodynamics. Therefore, the energy efficiency of the CHP unit was raised by 1.97\% (absolute value), because of the sharp exergy efficiency increase of the heating process as a result of the improved configuration.

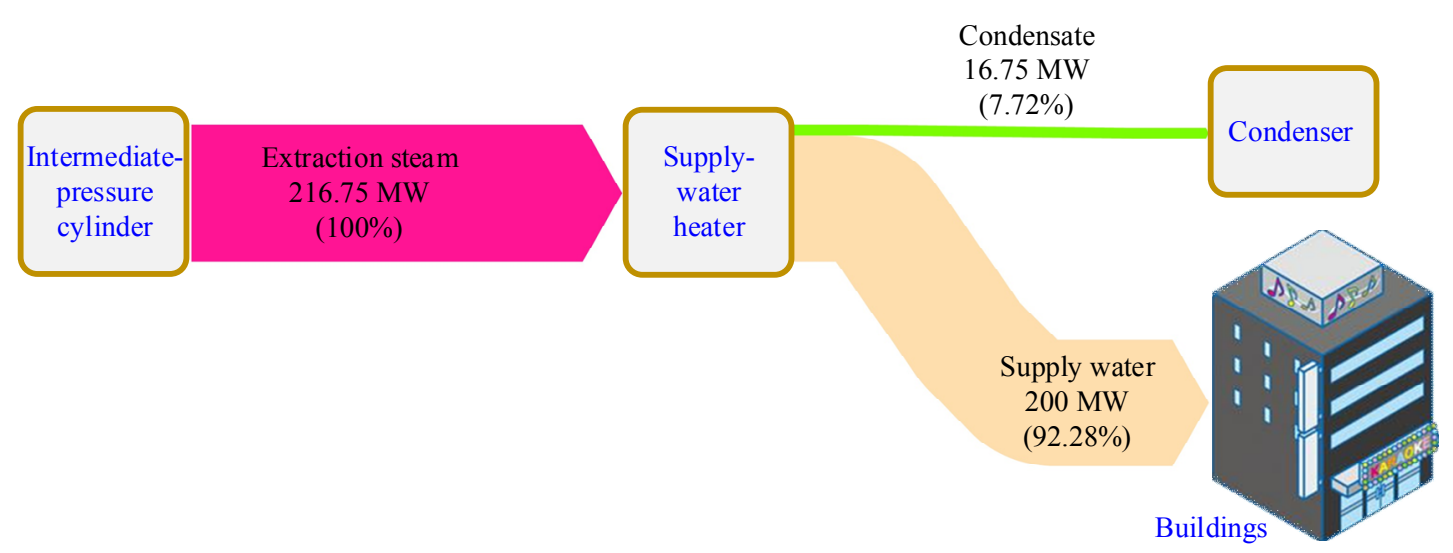

(a)

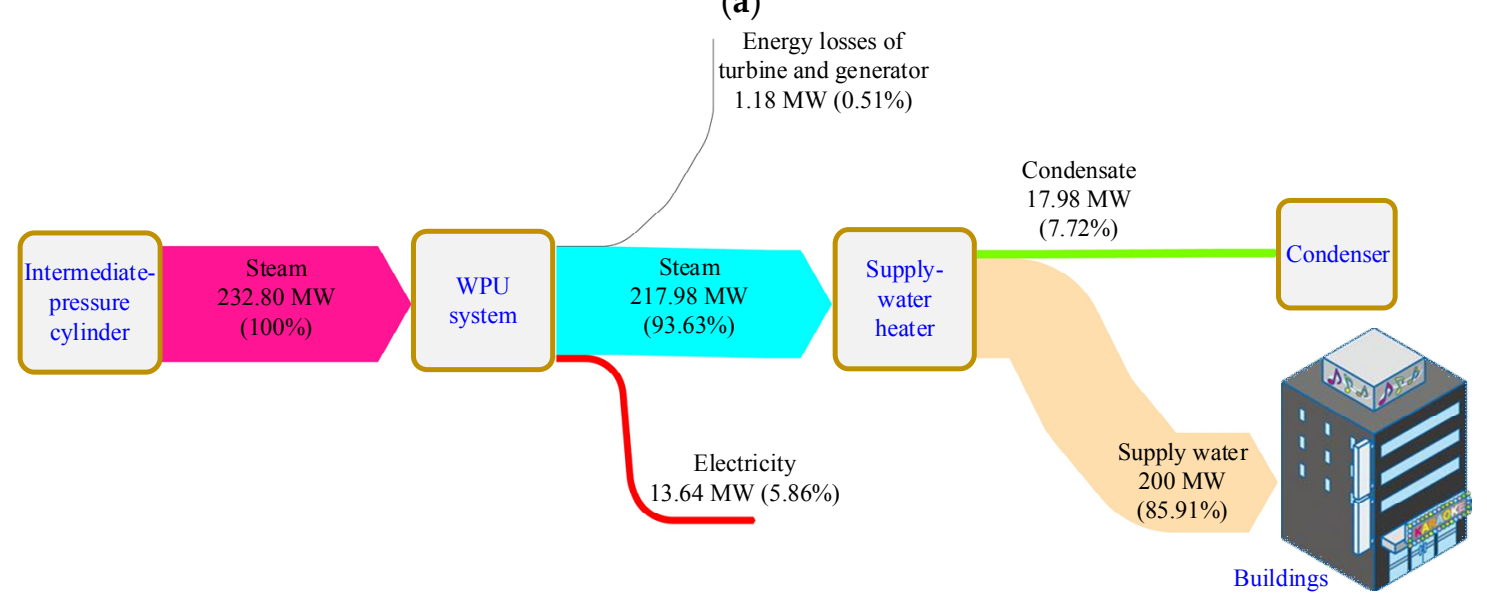

(b)

Figure 6. Energy flow diagrams of the original and proposed heating processes. (a) Original heating process; (b) proposed heating process.

On the basis of the above analysis results, the energy-saving characteristic of the proposed WPU concept is summarized in Figure 9. Because the improved heating system could take full advantage of the waste pressure, it would promote the overall efficiency of the CHP unit and bring great economic benefits. 


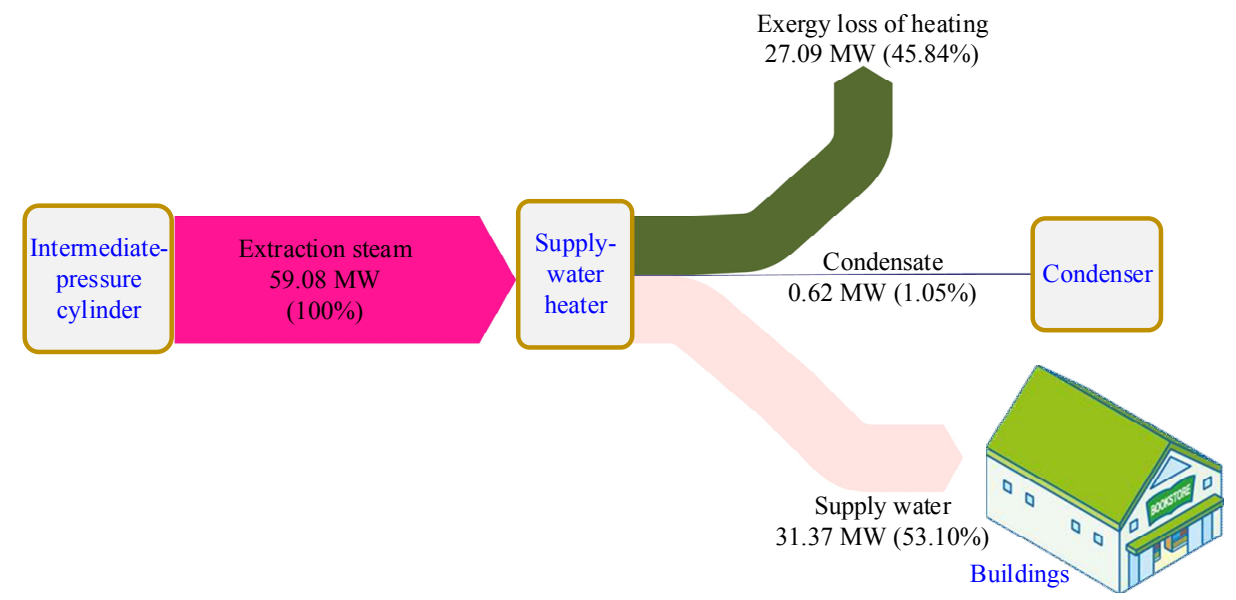

(a)

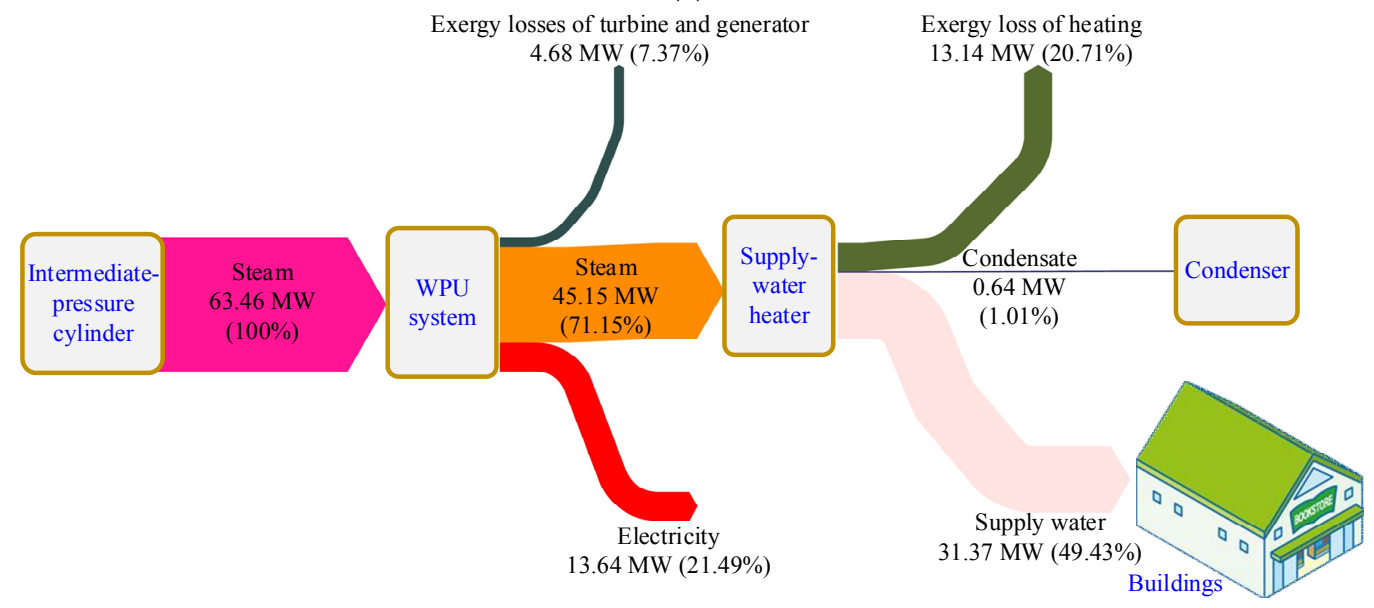

(b)

Figure 7. Exergy flow diagrams of the original and the proposed heating processes. (a) Original heating process; (b) proposed heating process. MW-heat.

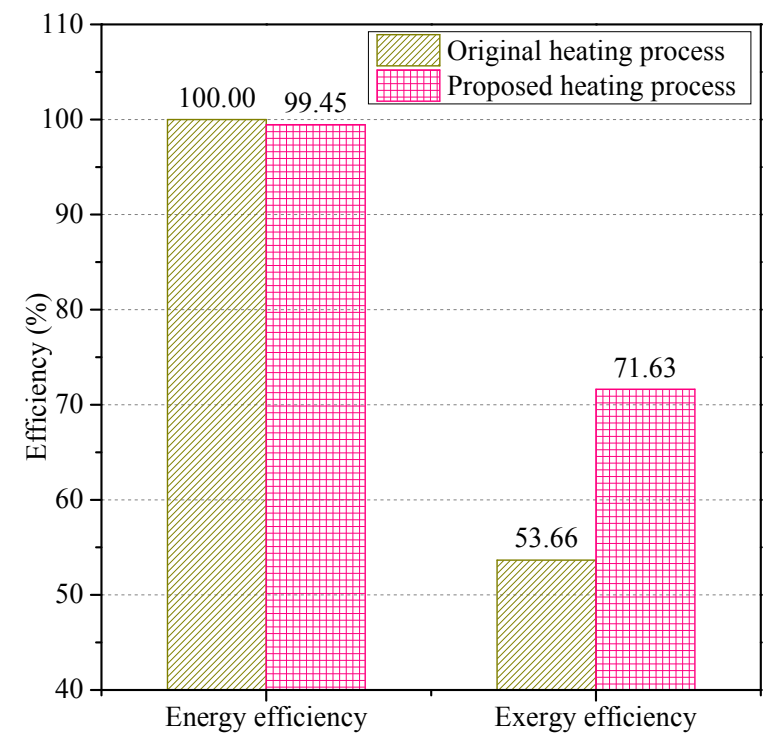

Figure 8. Energy and exergy efficiencies of the original and proposed heating processes. 


\subsection{Sensitivity Analysis}

To qualitatively discover the impacts of the main parameters (the unit generation load, the unit heating load, and the supply and return-water temperatures) on the proposed heating system, the performances of the original and improved units were comprehensively studied under different conditions. The isentropic efficiency of the WPU turbine and the generation efficiency of the WPU generator were regarded as constant, assuming that the efficiency of the WPU system was unchanged.

Figure 10 shows the thermal performance variations of the original and proposed CHP units with the total unit generation load. As the unit generation load increased, the thermal efficiencies of the two units went down, and the standard coal consumption rates rose. At the same time, the standard coal that was saved by the WPU design per kilowatt-hour became less. It seemed that cutting down the unit generation load contributed to a higher thermal efficiency and a lower fuel consumption rate. The generation power of the WPU system was inversely proportional to the unit generation load, but it did not change much, even the unit generation load varied from $160 \mathrm{MW}$ to $280 \mathrm{MW}$.

The influence of the unit heating load on the two CHP units is presented in Figure 11. When the unit heating load went up, the thermal efficiencies increased and the thermal efficiency promotion owing to the proposed design got larger. Meanwhile, the standard coal consumption rates declined and the WPU configuration contributed to saving more fuel. The generation of power of the WPU system rose obviously with the increase of the unit heating load. One reason for this could have been that a lot more steam would have been extracted from the intermediate cylinder in order to heat the supply-water and do more work in the WPU system under a high heating load of the unit.

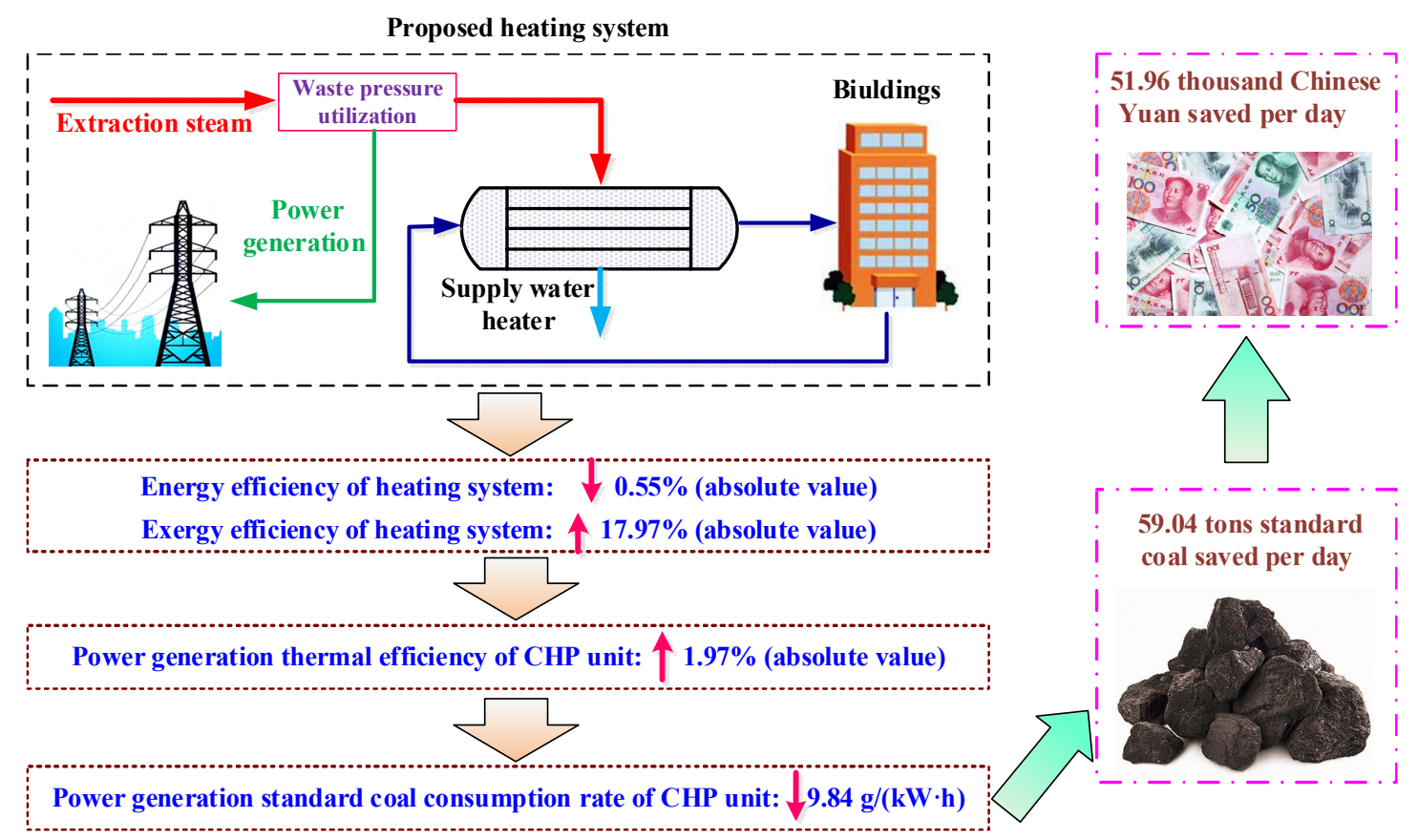

Figure 9. Energy-saving characteristic of the proposed concept with WPU. 


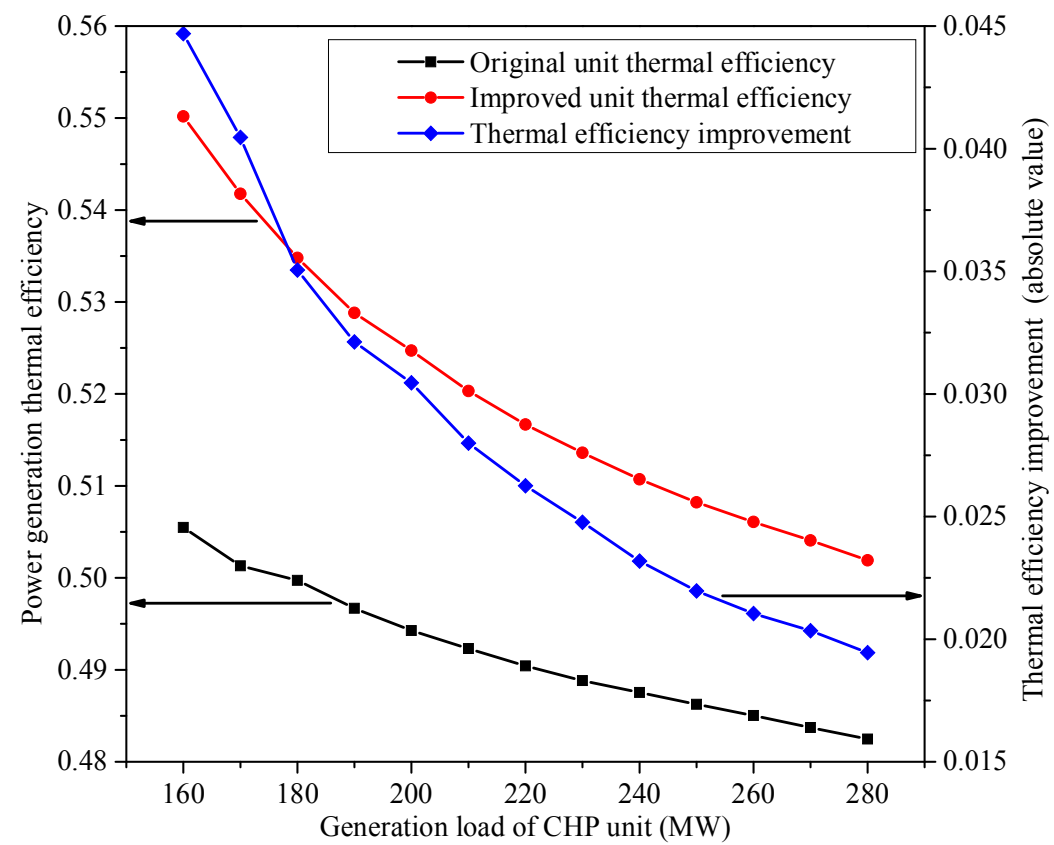

(a)

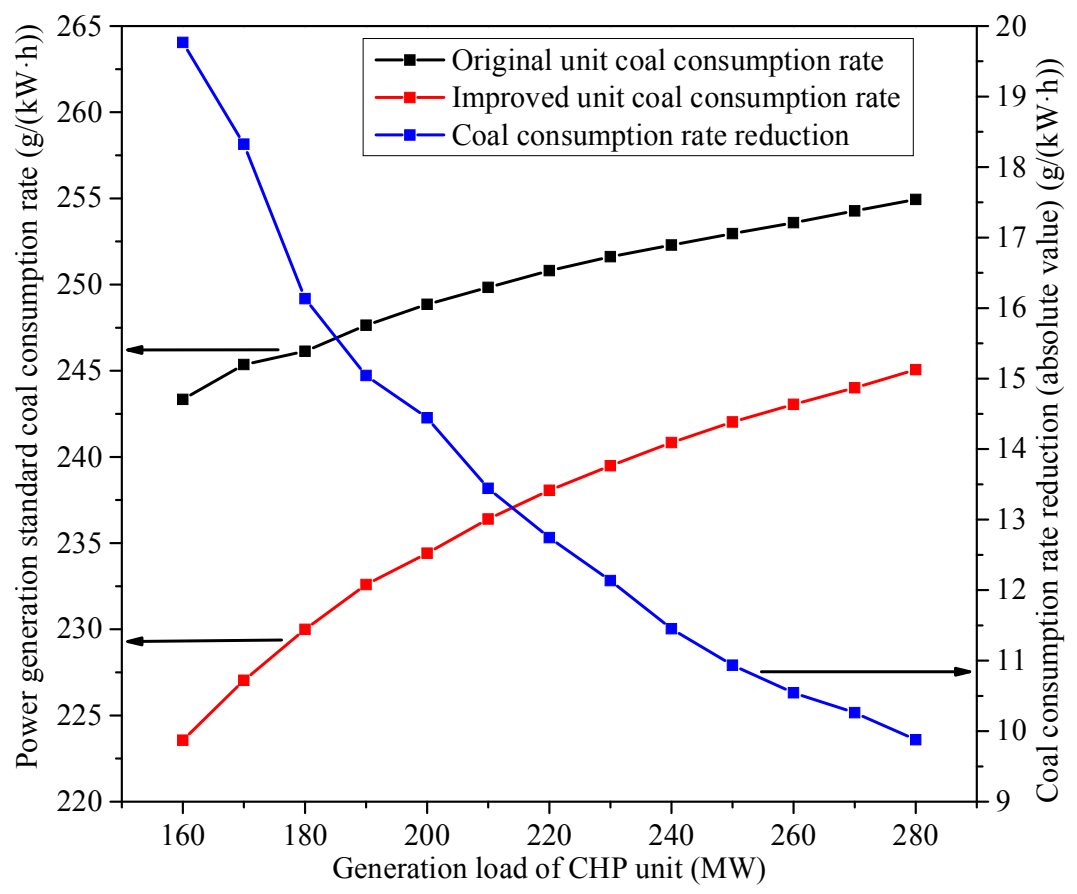

(b)

Figure 10. Cont. 


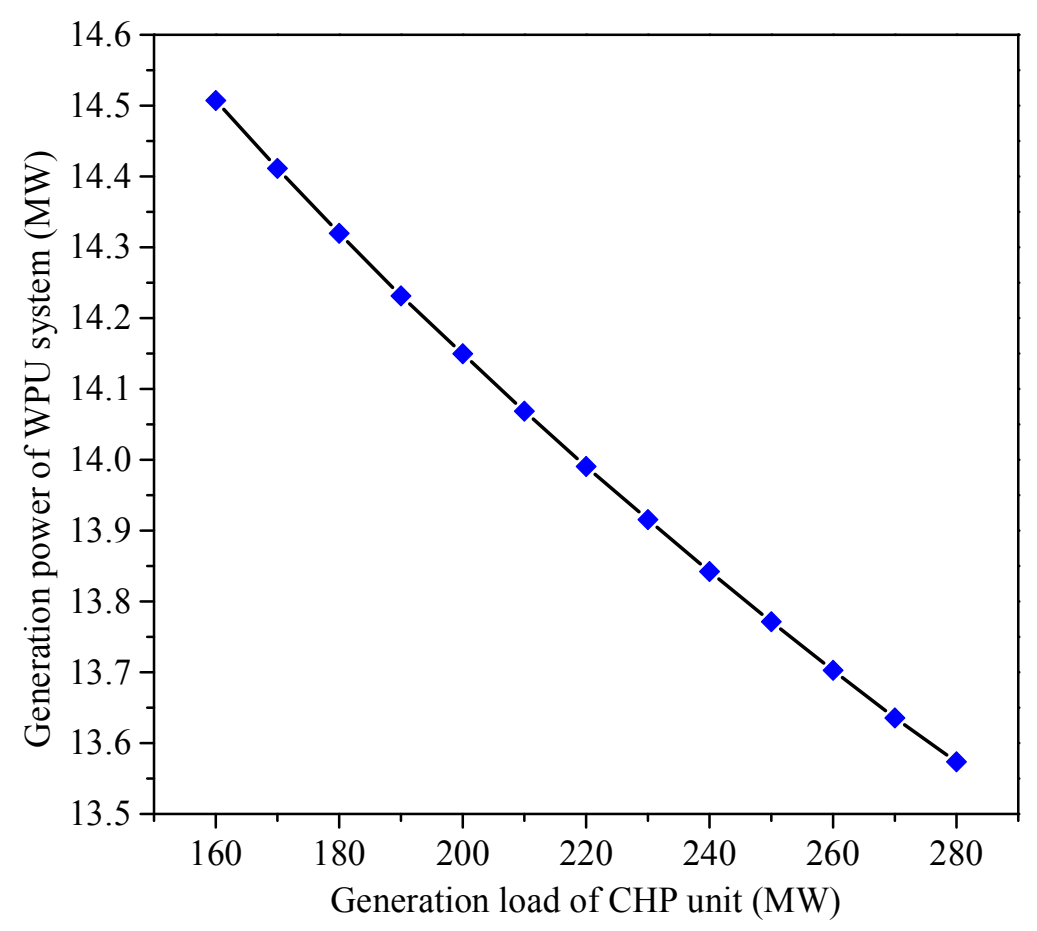

(c)

Figure 10. Effect of the unit generation load on the thermal performances of the original and improved CHP units (the unit heating load was set as $200 \mathrm{MW}$, and the supply and return-water temperatures were set as $95^{\circ} \mathrm{C}$ and $50{ }^{\circ} \mathrm{C}$ ). (a) Power generation thermal efficiency; (b) power generation standard coal consumption rate; and (c) generation of power of the WPU system.

According to the supply and return-water temperatures in the different months of the heating season from October 2016 to April 2017 (Figure 3), the relationships between the thermodynamic characteristics of the two units and the supply and return-water temperatures were investigated, as presented in Figure 12. The power generation thermal efficiency and the standard coal consumption rate of the original unit were not affected by the supply and return-water temperatures, but the thermal efficiency of the improved unit had a negative correlation with the water temperatures, and the standard coal consumption rate of the improved unit was positively related to the water temperatures. The generation of power of the WPU system increased significantly with the decrease of the water temperatures, because much more excess pressure of the extraction steam could be utilized for electricity generation before heating the supply-water (the needed heating steam pressure declined with the drop of the supply-water temperature, as shown in Table 2). In summary, the lower the supply and return-water temperatures were, the more power the WPU system generated, and the less fuel the proposed unit would burn per kilowatt-hour. 


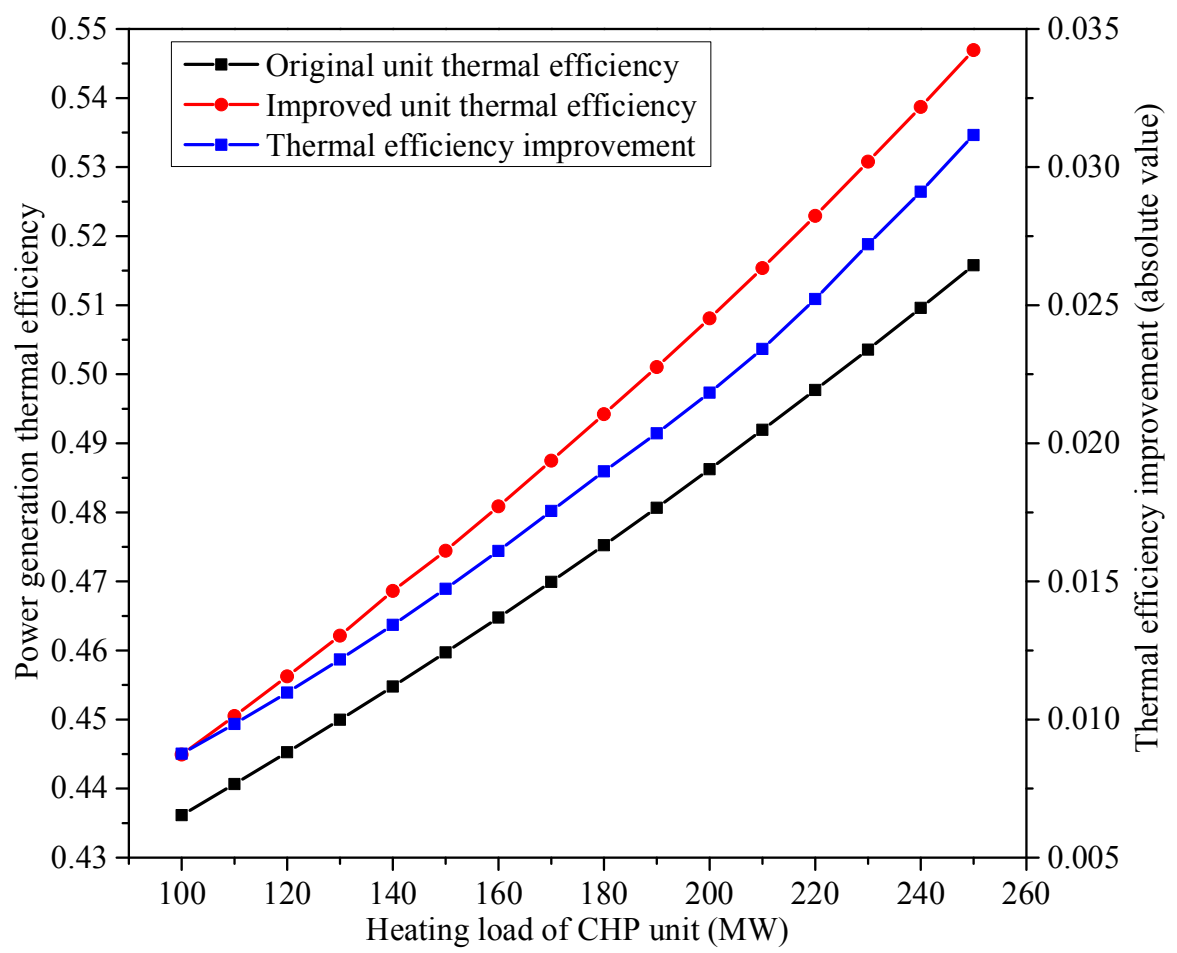

(a)

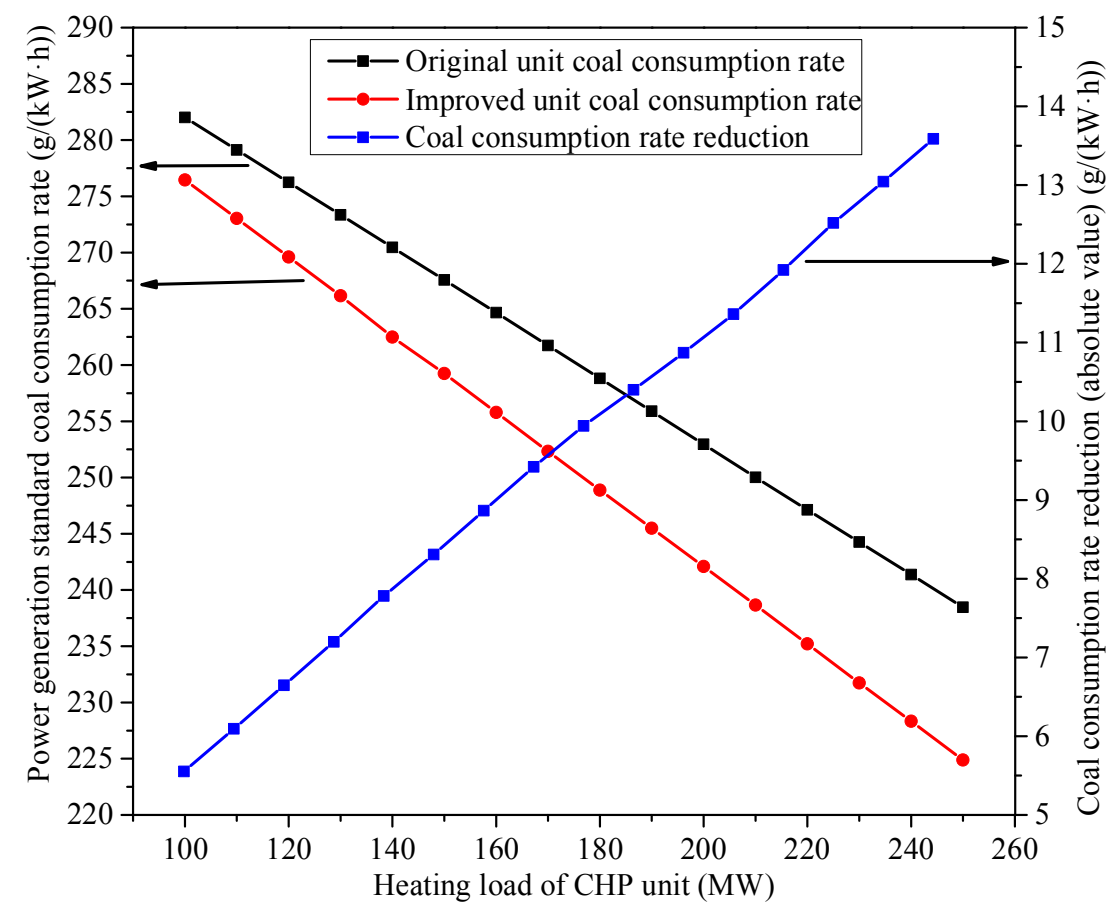

(b)

Figure 11. Cont. 


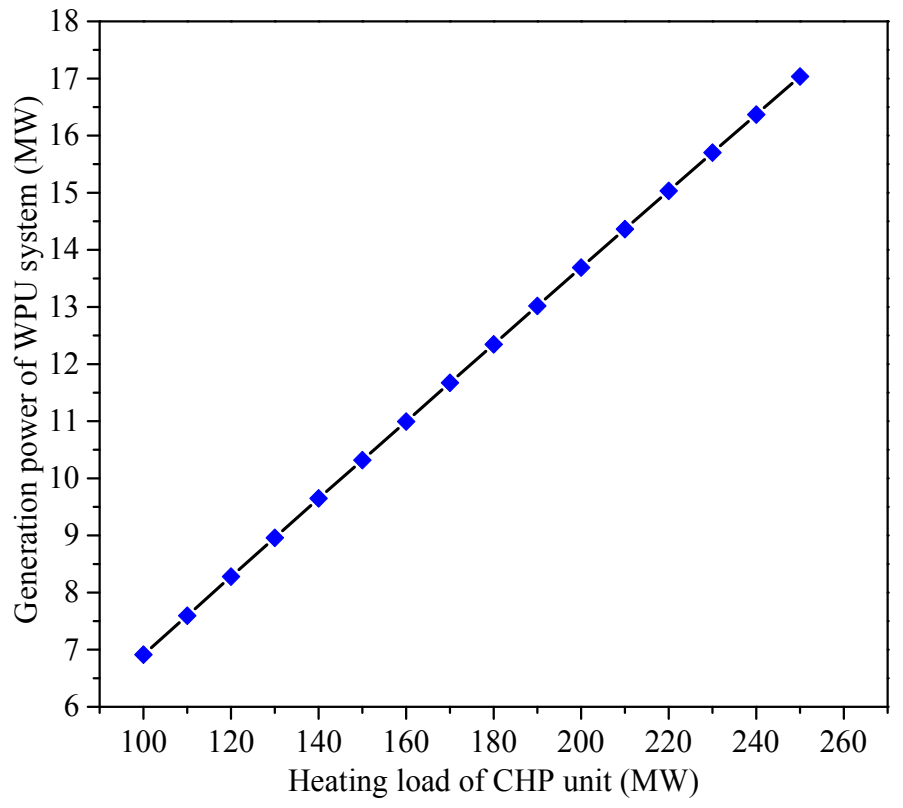

(c)

Figure 11. Effect of the unit heating load on the thermal performances of the original and improved $\mathrm{CHP}$ units (the unit generation load was set as $250 \mathrm{MW}$, and the supply and return-water temperatures were set as $95^{\circ} \mathrm{C}$ and $50{ }^{\circ} \mathrm{C}$ ). (a) Power generation thermal efficiency; (b) power generation standard coal consumption rate; and (c) generation of power of the WPU system.

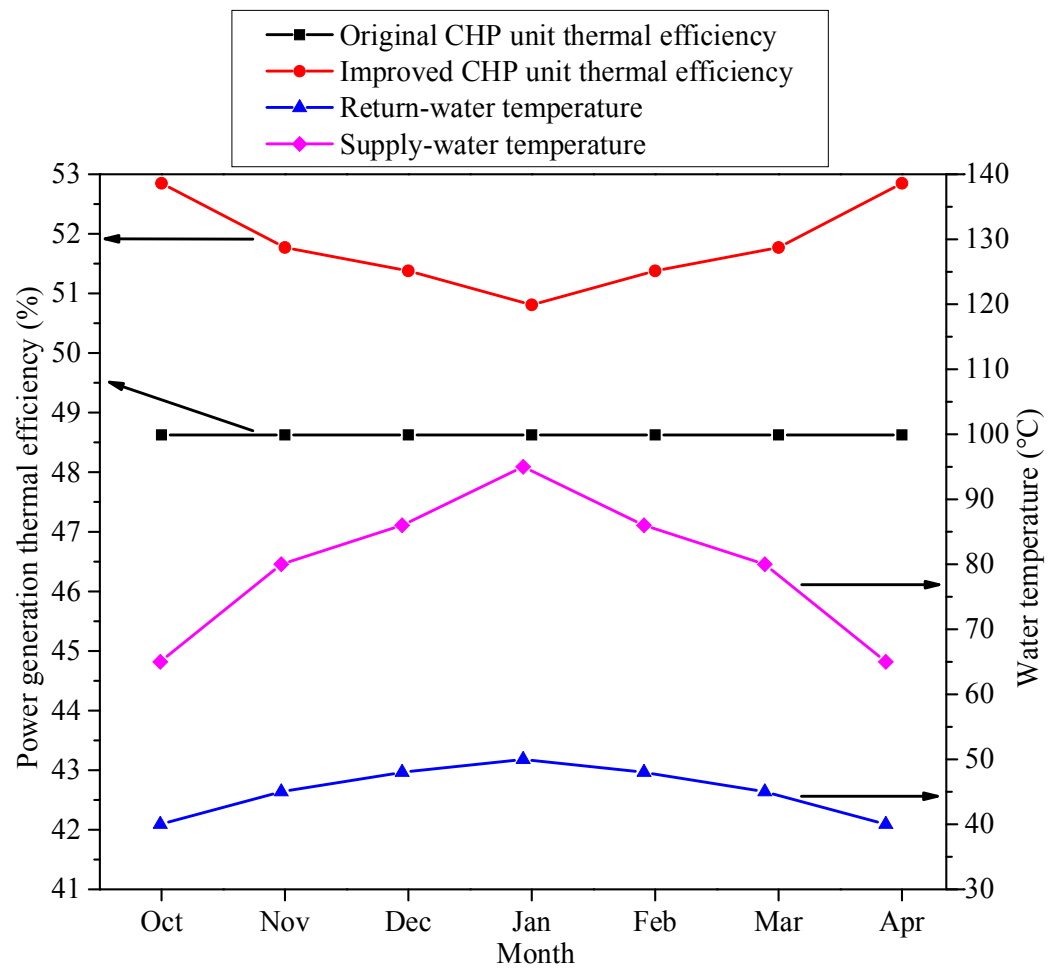

(a)

Figure 12. Cont. 


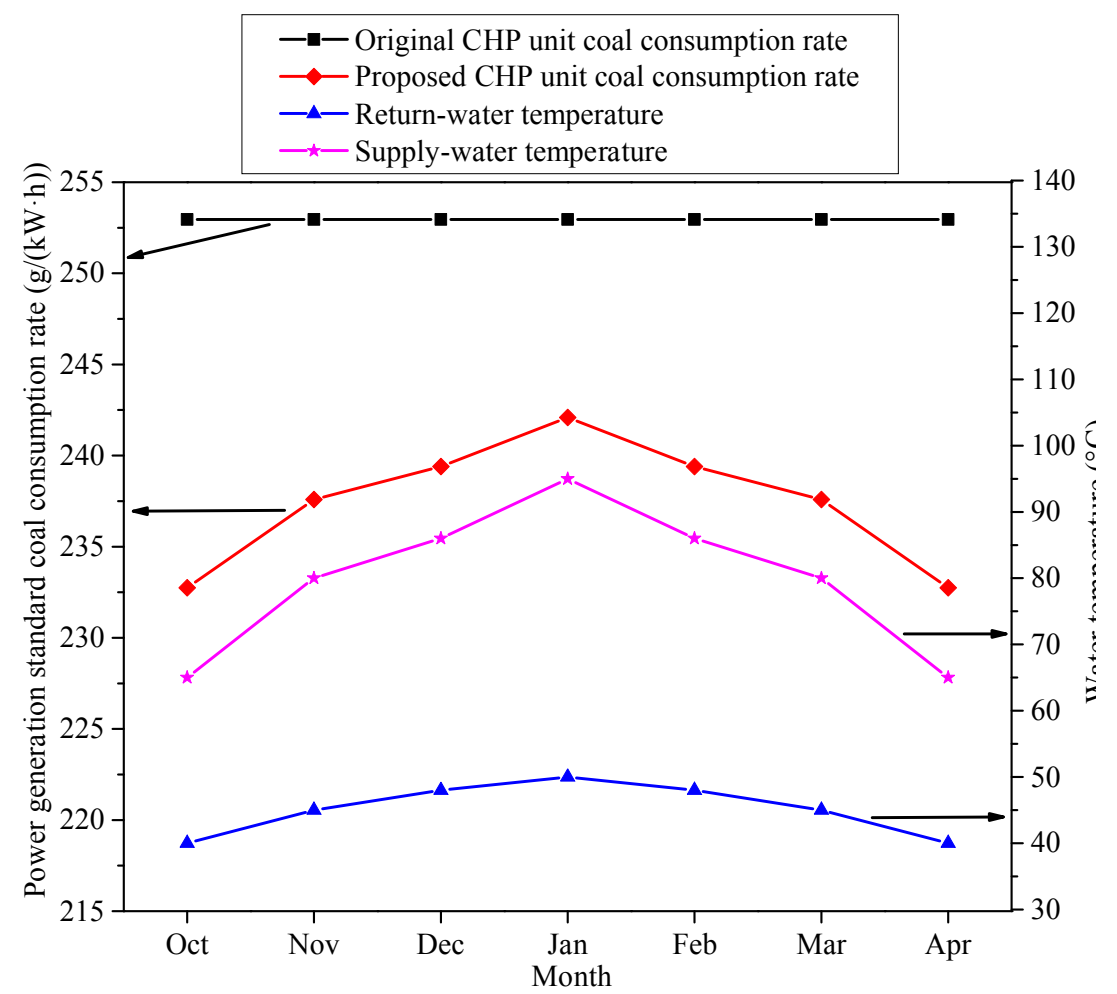

(b)

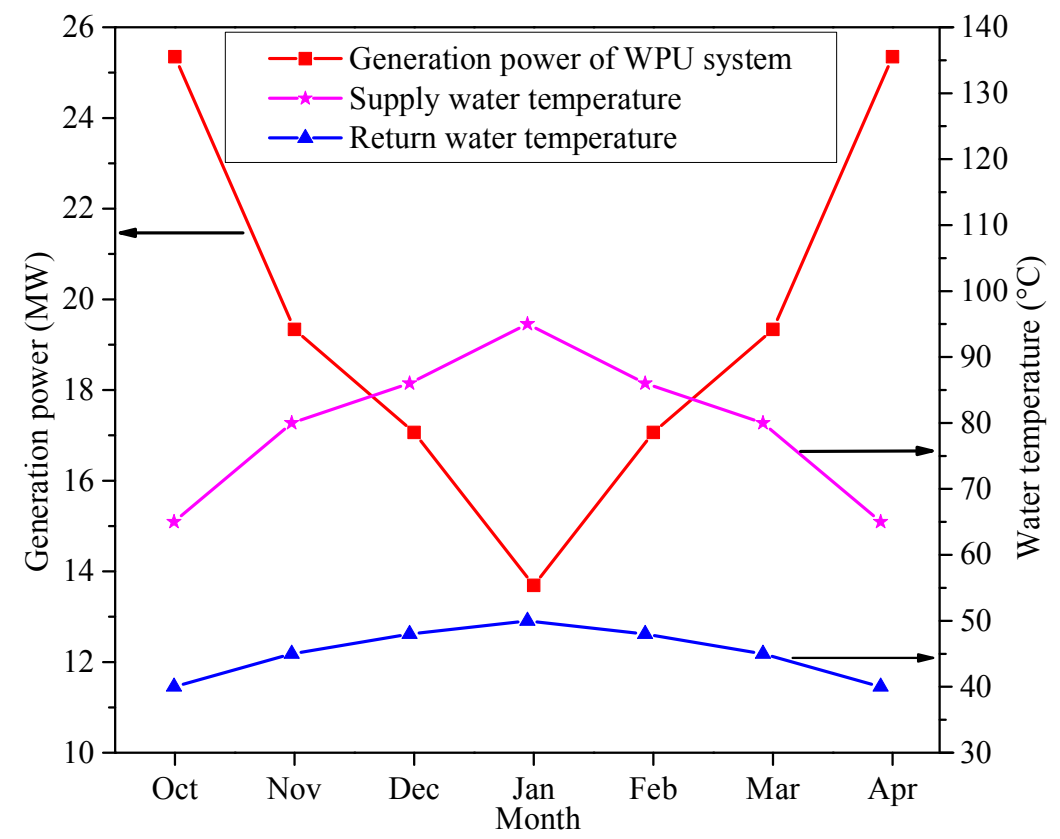

(c)

Figure 12. Effect of the supply and return-water temperatures on the thermal performances of the original and improved CHP units (the unit heating load and generation load were set as $200 \mathrm{MW}$ and $250 \mathrm{MW}$, respectively). (a) Power generation thermal efficiency; (b) power generation standard coal consumption rate; and (c) generation of power of the WPU system.

\section{Conclusions}

An improved heating system with WPU for CHP has been proposed. The quantitative analysis from the viewpoint of thermodynamics was comprehensively carried out on a 300 MW CHP unit, 
without and with the new concept. The results show that the improved configuration with WPU is productive and reliable, which is conducive to promoting the CHP unit efficiency, by making use of the extra pressure to generate electricity. The following conclusions are detailed as follows:

(1) The proposed heating system with WPU can reduce the power generation standard coal consumption rate of the unit by $9.84 \mathrm{~g} /(\mathrm{kW} \cdot \mathrm{h})$ with the power generation thermal efficiency improvement of $1.97 \%$ (absolute value). If operating under the rated heating condition for a whole day, the unit with the new design can save 59.04 tons of standard coal and 519,600 Chinese Yuan.

(2) The energy efficiency of the heating process decreases by $0.55 \%$ (absolute value) because of the proposed design, but its exergy efficiency rises by $17.97 \%$ (absolute value), which is caused by WPU. The new configuration utilizes the extraction steam's energy more fully and promotes the overall efficiency of the CHP unit.

(3) With the decreases of the unit generation load and supply, return-water temperatures, and the increase of the unit heating load, the power generation thermal efficiency of the CHP unit is further improved by the proposed concept and more fuel can be saved accordingly.

Author Contributions: Conceptualization: H.C. and G.X.; data curation: H.C. and J.X.; formal analysis: H.C., J.X. and Y.X.; funding acquisition: G.X. and Y.Y.; investigation: Y.X. and Z.Q.; methodology: Y.X.; resources: Z.Q.; software: J.X. and Y.X.; supervision: G.X. and Y.Y.; writing (original draft): H.C., J.X. and Z.Q.; and writing (review and editing): G.X. and Y.Y.

Acknowledgments: This work was supported by the National Nature Science Fund of China (No. 51476053), the National key R\&D Program of China (No. 2017YFB0602104), and the Fundamental Research Funds for the Central Universities (No. 2015ZZD10 and No. 2017ZZD003).

Conflicts of Interest: The authors declare no conflict of interest.

\section{Nomenclature}

$\begin{array}{ll}Q & \text { heat (MW) } \\ m & \text { flow rate }(\mathrm{t} / \mathrm{h}) \\ h & \text { specific enthalpy }(\mathrm{kJ} / \mathrm{kg}) \\ P & \text { generation power }(\mathrm{MW}) \\ E & \text { exergy }(\mathrm{MW}) \\ \text { Greek } & \text { Symbols: } \\ \delta & \text { relative error } \\ \eta & \text { efficiency } \\ \text { Subscripts: } \\ \text { tp } & \text { thermal power } \\ 0 & \text { initial } \\ \mathrm{b} & \text { boiler } \\ \mathrm{e} & \text { electricity } \\ \mathrm{fw} & \text { feed-water } \\ \mathrm{rh} & \text { reheated } \\ \text { en } & \text { Energy } \\ \text { ex } & \text { Exergy } \\ \mathrm{p} & \text { pipe/practical } \\ \mathrm{c} & \text { cold/calculated }\end{array}$

\section{References}

1. Elmegaard, B.; Ommen, T.S.; Markussen, M.; Iversen, J. Integration of space heating and hot water supply in low temperature district heating. Energy Build. 2016, 124, 255-264. [CrossRef]

2. Athawale, R.; Felder, F.A.; Goldman, L.A. Do combined heat and power plants perform? Case study of publicly funded projects in New York. Energy Policy 2016, 97, 618-627. [CrossRef]

3. Ghorbani, N. Combined heat and power economic dispatch using exchange market algorithm. Int. J. Electr. Power 2016, 82, 58-66. [CrossRef] 
4. Zhang, G.; Cao, Y.; Cao, Y.; Li, D.; Wang, L. Optimal energy management for microgrids with combined heat and power (CHP) generation, energy storages, and renewable energy sources. Energies 2017, 10, 1288. [CrossRef]

5. Mago, P.J.; Smith, A.D. Evaluation of the potential emissions reductions from the use of CHP systems in different commercial buildings. Build. Environ. 2012, 53, 74-82. [CrossRef]

6. Tsai, W. Regulatory Compliance and Environmental Benefit Analysis of Combined Heat and Power (CHP) Systems in Taiwan. Energies 2013, 6, 557-565. [CrossRef]

7. Comodi, G.; Rossi, M. Energy versus economic effectiveness in CHP (combined heat and power) applications: Investigation on the critical role of commodities price, taxation and power grid mix efficiency. Energy 2016, 109, 124-136. [CrossRef]

8. Sartor, K. Simulation models to size and retrofit district heating systems. Energies 2017, 10, 2027. [CrossRef]

9. Zhang, J.; Cho, H.; Knizley, A. Evaluation of financial incentives for combined heat and power (CHP) systems in U.S. regions. Renew. Sustain. Energy Rev. 2016, 59, 738-762. [CrossRef]

10. Waqar, A.; Tanveer, M.S.; Ahmad, J.; Aamir, M.; Yaqoob, M.; Anwar, F. Multi-objective analysis of a CHP plant integrated microgrid in Pakistan. Energies 2017, 10, 1625. [CrossRef]

11. Guo, Y.; Zhang, X.; Yang, L.; Xu, C.; Du, X. The heat transfer of microencapsulated phase change material slurry and its thermal energy storage performance of combined heat and power generating units. Energies 2017, 10, 1662. [CrossRef]

12. Sun, S. Research on Engineering Application of Cascade Heating Technology with High Back-Pressure; North China Electric Power University: Beijing, China, 2017. (In Chinese)

13. Athawale, R.; Felder, F.A. Incentives for combined heat and power plants: How to increase societal benefits? Util. Policy 2014, 31, 121-132. [CrossRef]

14. Ge, Z.; Zhang, F.; Sun, S.; He, J.; Du, X. Energy analysis of cascade heating with high back-pressure large-scale steam turbine. Energies 2018, 11, 119. [CrossRef]

15. Ge, Z.; Sun, S.; Wan, Y.; Zhao, S.; He, J. Applicability analysis of high back-pressure heating retrofit for large-scale steam turbine unit. Proc. CSEE 2017, 27, 3216-3222, 3377. (In Chinese)

16. Byun, S.; Park, H.; Yi, S.; Song, C.; Choi, Y.; Lee, S.; Shin, J. Study on the optimal heat supply control algorithm for district heating distribution network in response to outdoor air temperature. Energy 2015, 86, 247-256. [CrossRef]

17. Academy of Machinery Science and Technology. Heater for Heating Network; JB/T 7837-1995; Ministry of Machinery Industry of People's Republic of China: Beijing, China, 1995. (In Chinese)

18. Li, Y.; Wang, W.; Ma, Y.; Li, W. Study of new cascade heating system with multi-heat sources based on exhausted steam waste heat utilization in power plant. Appl. Therm. Eng. 2018, 136, 475-483. [CrossRef]

19. Li, Y.; Fu, L.; Zhang, S.; Zhao, X. A new type of district heating system based on distributed absorption heat pumps. Energy 2011, 36, 4570-4576. [CrossRef]

20. Sun, F.; Fu, L.; Sun, J.; Zhang, S. A new waste heat district heating system with combined heat and power (CHP) based on ejector heat exchangers and absorption heat pumps. Energy 2014, 69, 516-524. [CrossRef]

21. Kang, S.; Li, H.; Lei, J.; Liu, L.; Cai, B.; Zhang, G. A new utilization approach of the waste heat with mid-low temperature in the combined heating and power system integrating heat pump. Appl. Energy 2015, 160, 185-193. [CrossRef]

22. Soltani, R.; Dincer, I.; Rosen, M.A. Thermodynamic analysis and performance assessment of an integrated heat pump system for district heating applications. Appl. Therm. Eng. 2015, 89, 833-842. [CrossRef]

23. Shukla, A.K.; Singh, O. Thermodynamic investigation of parameters affecting the execution of steam injected cooled gas turbine based combined cycle power plant with vapor absorption inlet air cooling. Appl. Therm. Eng. 2017, 122, 380-388. [CrossRef]

24. Feng, P.; Wang, N.; Yang, Z.; Li, X.; Yang, Y. Cascade heating characteristics and off-design collaborative optimization of direct air-cooled high-pressure heat supply power units. Proc. CSEE 2016, 36, 5546-5554, 5731. (In Chinese)

25. Wang, L. Modification Technology and Operation Optimization of 300 MW High Back Pressure Heat Supply Power Unit; North China Electric Power University: Beijing, China, 2017. (In Chinese)

26. Li, Y.; Fu, L.; Zhang, S.; Jiang, Y.; Xiling, Z. A new type of district heating method with co-generation based on absorption heat exchange (co-ah cycle). Energy Convers. Manag. 2011, 52, 1200-1207. [CrossRef] 
27. Li, Y.; Fu, L.; Zhang, S. Technology application of district heating system with co-generation based on absorption heat exchange. Energy 2015, 90, 663-670. [CrossRef]

28. Sun, F.; Fu, L.; Zhang, S.; Sun, J. New waste heat district heating system with combined heat and power based on absorption heat exchange cycle in China. Appl. Therm. Eng. 2012, 37, 136-144. [CrossRef]

29. Sun, J.; Fu, L.; Zhang, S. Experimental study of heat exchanger basing on absorption cycle for CHP system. Appl. Therm. Eng. 2016, 102, 1280-1286. [CrossRef]

30. Qian, S. Heat Exchanger Design Handbook; China Petrochemical Press: Beijing, China, 2006. (In Chinese)

31. Zheng, T. Thermal Energy \& Power, 2nd ed.; China Electric Power Press: Beijing, China, 2008. (In Chinese)

32. Coal Price Index. Available online: https://www.cngold.org/c/2018-03-30/c5723725.html (accessed on 30 March 2018). (In Chinese)

(C) 2018 by the authors. Licensee MDPI, Basel, Switzerland. This article is an open access article distributed under the terms and conditions of the Creative Commons Attribution (CC BY) license (http:/ / creativecommons.org/licenses/by/4.0/). 